\title{
E-GOVERNMENT AS A SMART SOLUTION FOR PUBLIC ADMINISTRATION: A CASE OF VISEGRAD GROUP
}

\author{
Ingrid Majerova ${ }^{1}$
}

Received: June 16, 2019 / Revised: July 24, 2019/ Accepted: October 15, 2019

(C) Association of Economists and Managers of the Balkans, 2019

\begin{abstract}
More than fifteen years ago, through the benchmarking method, the United Nations began to carry out a survey of the electronisation level of public administration - e-government. Three areas of its level - online services, telecommunication infrastructure and human capital have been summarized into a single index called E-government Development Index (EGDI). The main objective of this research was to provide an overview of the current status of the Visegrad Group (Czech Republic, Hungary, Poland and Slovakia) in EGDI development and compare the level of this index. The results show firstly that the monitored group of countries are placed at the end of EU ranking and secondly that while Poland has improved its level, the Czech Republic is lagging behind.
\end{abstract}

Keywords: E-government Development Index, Min-max Method, Czech Republic, Hungary, Poland, Slovakia

JEL Classification I38 $\cdot \mathbf{O 3 8} \cdot \mathbf{R} 59$

This paper was presented at the Fifth International Scientific Conference on Knowledge Based Sustainable Development - ERAZ 2019 - May 23, Budapest, Hungary, www.eraz.org.rs

Ingrid Majerova

majerova@opf.slu.cz

1 Silesian University in Opava, School of Business Administration in Karvina, Univerzitni nam. 1934/3, 73340 Karvina, Czech Republic 


\section{INTRODUCTION}

The digital environment is a standard phenomenon of the twenty-first century. One of its part is electronisation of public administration, known as e-government. The electronic public sphere should be able to improve and simplify public administration activities through information and communication technologies, which can make a significant contribution to the lives of millions of people. Simply said, this should be smart solution for all economic subject. As claimed Gupta and Jana, already in 2003, electronic government is no longer just an option but a necessity for countries aiming for better governance (Gupta and Jana, 2003).

The question of how to evaluate e-government at various levels (local and national) is still actual and debate are very critical (for more see Whitmore, 2012) till nowadays. However, the most prominent and used ranking of e-government level remains the measurement of United Nations Public Administration Network (UNPAN), which includes 193 member countries. E-government development index (EGDI) is composite measurement of three sub-indices i.e. online services, telecommunication and human capital. These three sub-indices are also calculated from four indicators in online services group, five in telecommunication group and two in human capital group which can be analyzed independently.

The objective of this research is to provide an overview of the current status of the Visegrad Group countries (the Czech Republic, Hungary, Poland and Slovakia) in e-government development using United Nation e-government survey reports as the main source of documents. The main motivation for writing this paper is based on the OECD (2009) opinion that rich countries tend to be technology savvy and show high intensity of ICT usage. Likewise, Fernández-iMarín (2011) claims that empirical studies show that GDP per capita correlates highly with use of e-government. ICT have come to represent the factors that determine successful development of e-government. The E-government Development Index, therefore, measures the capacity and willingness of the public sector to deploy ICT for improving knowledge and information in the service of the citizen (United Nations, 2012). This should mean that in the Visegrad Group countries, there is a high level of government and that level is constantly improving. Another reason of motivation was the absence of any study comparing this historically and politically very close group of countries in this area of research.

This paper is structured as follows: Second section describes the approaches to the issue of e-government. Third section discusses the research methodology with used methods and dataset. Fourth section summarizes results with the obtained data of comparison of monitored countries and discusses the results of analysis. In the fifth section will be concluded the obtained facts of this paper.

\section{LITERATURE REVIEW}

According to Halchin (2004), there is no universally agreed upon definition of the e-government concept. Donna and Yen (2006) claimed that e-government means the government and public communicate with each other through computers which increases efficiency and effectiveness and reduce the cost. Budiš et al. (2008) define e-government as the use of information technology by public institutions to ensure the exchange of information with citizens, private organizations and other public institutions in order to increase the efficiency of internal functioning and provide fast, accessible and quality information services. Belanger and Carter (2008) are of the opinion that the concept of e-government is defined in more detail, as the utilization of information technology 
(especially telecommunication) to enable and improve the efficiency with the government services and information provided to different stakeholders of the e-government.

Alshomrani (2012) claims that e-government is multidimensional and complicated concept in nature, therefore different views about the concept reflects various focuses on interest by governments, organizations and researchers. According to Alzahrani (2011), e-government has a significant impact on the performance of public sector as a result continuous growth has been seen in the e-governments development around the world since last two decades. The term e-government indicates the possibility to communicate with state and public institutions in electronic form (Criado, 2012). Governments use e-government as a vehicle to drive national digital economy, which promises better human and sustainable development, and building of more democratic societies WEF(2013). As Šperka (2014) claimed, the main goal of e-government is principally to make the public contact with offices easier (mainly from the time point of view) which goes for the citizens as well as for the companies.

According to the new EU e-government Action Plan 2016-2020 public administrations and public institutions in the European Union should be open, efficient and inclusive, providing borderless, personalised, user-friendly, end-to-end digital public services to all citizens and businesses in the EU. Innovative approaches are used to design and deliver better services in line with the needs and demands of citizens and businesses. Public administrations use the opportunities offered by the new digital environment to facilitate their interactions with stakeholders and with each other EC (2016).

To sum up, e-government is a permanent public administration obligation to improve the relationship between citizens and the public sector by providing cheap and efficient services, information and knowledge independent of time constraint and geographical location. It is practical implementation of the best that the public administration can offer.

\section{METHODOLOGY}

Almost twenty years ago, the United Nations began to conduct e-government research through benchmarking. The UN survey includes a brief description and evaluation of e-government developments, and it is the only global report that evaluates it in all $193 \mathrm{UN}$ member countries. The main aim of the survey is to identify strong points, problems and the choice of e-government policy strategy. The consistency of the e-government survey method is more evident from the evaluation published in UN Global e-government Survey 2003. The United Nations issued in the last decade of the biennial report, whose aim is to show an example of a successful e-government strategies, innovative practices with regard to administrative reform and sustainable development.

The EGDI index itself is composed of three subindexes: Online Service Index (OSI), Telecommunications Infrastructure Index (TII) and Human Capital Index (HCI).

For Online Service Index (OSI) data collected from an independent questionnaire from 89 countries (not all countries provide the online services). There are the questions about submitting the taxes, applying for various certificates - birth, marriage, death, driving license, personal ID etc. The exact methodology is a secret, but UN published some information about this process from 2018. 
Telecommunications Infrastructure Index (TII) collects data from the International Telecommunications Union (ITU) with the same weight:

- Estimated internet users per 100 inhabitants (who have used the internet from any location in the last 3 months) - 1/5 of TII,

- Number of fixed telephone subscriptions per 100 inhabitants - 1/5 of TII,

- Number of mobile cellular telephone subscriptions per 100 inhabitants - 1/5 of TII,

- Number of fixed (wired) broadband subscriptions per 100 inhabitants - 1/5 of TII,

- Active mobile-broadband subscriptions per 100 inhabitants - 1/5 of TII.

Data from UNESCO are served for calculation of Human Capital Index (HCI), which consists from:

- Adult literacy rate (has the biggest weight $1 / 3$ of $\mathrm{HCI}$ ),

- Gross enrolment ratio for primary, secondary and tertiary education, as a percentage of the population of school age for that level,

- Expected years of schooling; the total number of years a child of a certain age is expected to receive,

- Mean years of schooling.

Average number of years of education is completed by a country's adult population.

Each subindex is calculated by the min-max normalization method, see equation (1). Before that it is necessary to standardize the data for each EGDI component, according to equation (2), where after the standardization with z-score each component index shows a comparable deviation. The aim is to get values between $0-1$. If the z-score method were not used, EGDI would depend on the index of the most deviated component. After z-score standardization, the arithmetic mean becomes a suitable statistical indicator.

$$
S I_{c}=\frac{V_{c}-V_{\min }}{V_{\max }-V_{\min }}
$$

where $\mathrm{V}_{\mathrm{c}}$ is common value of subindex of country, $\mathrm{V}_{\min }$ is the minimum value of subindex and $\mathrm{V}_{\max }$ is the maximum of value of subindex.

$$
z=\frac{(\mathrm{x}-\mu)}{\sigma}
$$

where $x$ is a raw state that is intended for standardization, $z$ represents interspecies and mean deviations, $\mu$ is average of population (standard deviation of dataset) and $\sigma$ is the population standard deviation (standard deviation of dataset).

After these steps, the EGDI index can be calculated as the average of all subindexes, as shown in the equation (3).

$$
E G D I=\frac{O S I+T I I+H C I}{3}
$$

The EGDI index is then subdivided into four groups by result:

- very high EGDI, where the value of index is $>0.75$,

- high EGDI, where the value is between 0.5 and 0.75 ,

- middle EGDI, where the value is between 0.25 and 0.50 ,

- low EGDI, where the value is between 0 and 0.25 . 
The development of EGDI index in the world is shown in Figure 1 - the more green the higher level of e-government. There are compared the countries in the years 2005 (left side) and 2018 (right side) in the figure and is shown improvement, mostly in developing countries.
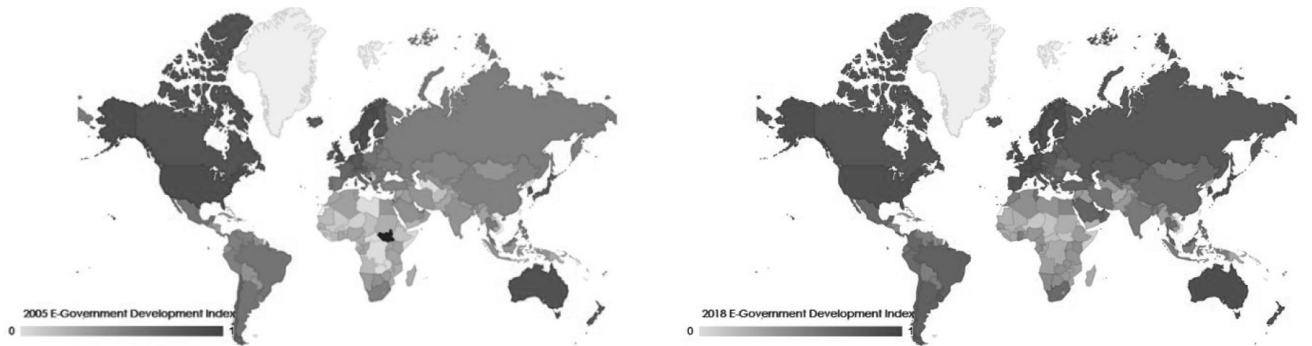

Figure 1. Development of EGDI in the world between 2005 and 2018

Source: United Nation, 2018

\section{RESULTS AND DISCUSSION}

When evaluating almost all the economies in the world, it is necessary to distinguish their achieved level of income - it is not possible to compare in the same way e.g. the USA and Namibia. Therefore, the UN lists the values of EGDI values for economies according to their income, based on the methodology of the World Bank. The average values for each income group are expressed in Figure 1. For illustrative purposes, the index development and its sub-indices in 2014 and 2018 are shown.
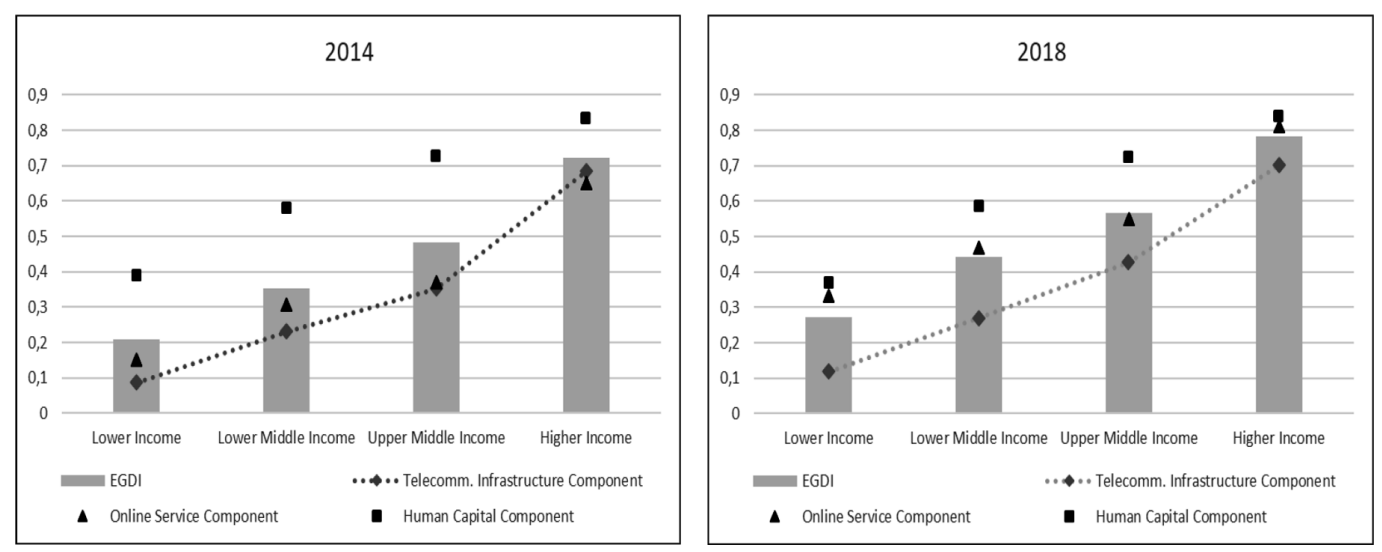

Figure 2. EGDI and its component indices for 2014 and 2018 Source: United Nation, 2018

It can be seen from the figure above that the overall index value for countries in various income groups differs significantly and improves in all cases between 2014 and 2018. A similar trend also occurs with the components of EGDI itself, when the highest improvement showed the area of online services. However, if EGDI is compared to high- and low-income countries, the value is still more than three times different.

Another comparison and criterion can be geographic location, as shown in the Table 1. However, this comparison is quite problematic - while Europe is to some extent homogeneous, it cannot be 
said about other continents. For example, the US is rated very high (0.8769), while Haiti (0.193) is located low. Similarly, in Asia - on one site is South Korea (0.8915) and on another Afghanistan (0.2585) or Africa with Mauritius (0.623) and Somalia (0.027).

Table 1. EDGI according to regions in 2018

Source: United Nations, 2018

\begin{tabular}{|c|c|c|c|c|}
\cline { 2 - 5 } \multicolumn{1}{c|}{} & EGDI & OSI & TII & HCI \\
\hline Africa & 0.2882 & 0.2567 & 0.1724 & 0.4355 \\
\hline America & 0.5245 & 0.4959 & 0.3844 & 0.6933 \\
\hline Asia & 0.5132 & 0.5120 & 0.3730 & 0.6545 \\
\hline Europe & 0.7241 & 0.6926 & 0.6438 & 0.8360 \\
\hline Pacific & 0.4154 & 0.2966 & 0.2599 & 0.6897 \\
\hline WORLD & 0.4922 & 0.4623 & 0.3711 & 0.6433 \\
\hline
\end{tabular}

What concerns the Visegrad group members, these are ranked to high income countries (with exception of Slovakia which is upper middle), but with lower values of EGDI, as it can be seen in Appendix. When we compare these countries among themselves, including the values of subindexes, we obtain the results shown in Figure 3. The best position has Poland (thanks a higher value of OSI), than Hungary, Slovakia and at the last place is the Czech Republic.

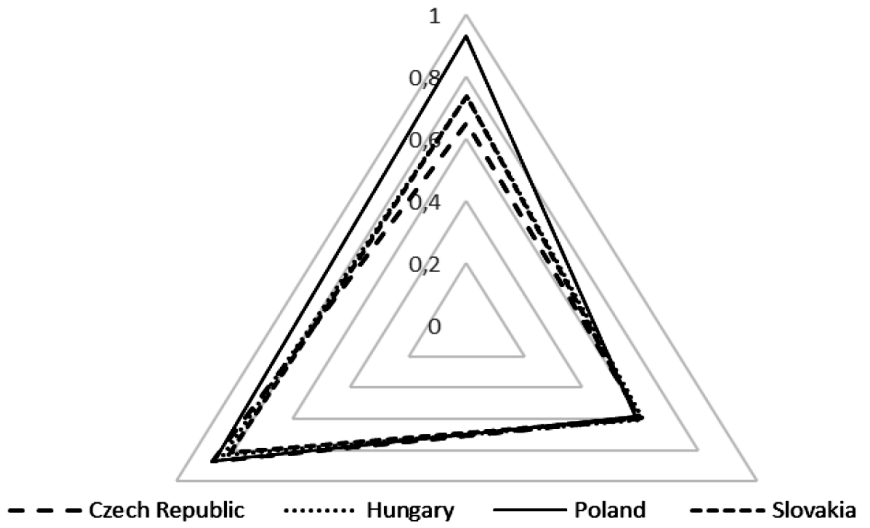

Figure 3. EDGI in Visegrad Group in 2018 Source: United Nation, 2018

From the Figure 3 is clear that all Visegrad Group countries are almost at the same level, the differences are not so high. Nevertheless, one exception exists and so the values of subindex OSI, where the lowest value (the Czech Republic with 0.6528 ) differs mostly $20 \%$ from the highest one, Poland (0.9306).

\section{FUTURE RESEARCH DIRECTIONS}

As claims the EU Action Plan 2016-2020 (Accelerating the digital transformation of government), in the future, public administrations and public institutions should be open, efficient and inclusive, providing borderless, personalised, user-friendly, end-to-end digital public services to all citizens and businesses. Innovative approaches are used to design and deliver better services in line with 
the needs and demands of citizens and businesses. Public administrations use the opportunities offered by the new digital environment to facilitate their interactions with stakeholders and with each other (EC, 2016). An example of good practice is Estonia, which is probably the one country in the world where $99 \%$ of the public services are available online every hour and every day.

By 2050 , the UN projects $66 \%$ of the world's population will live in urban environments. This raises many questions, in relation to public administration: How will governments give the estimated 6.3 billion people efficient access to public services? Answer could be interactive Smart e-Government, which provides its citizens with an especially responsive and efficient channel of service from public authorities and world-class infrastructure, services, and leisure resources, creating a rich environment in which they can enjoy well-rounded and fulfilling lives. Morover, Smart e-Government is the one strategy to preserve and even enhance services at a lower cost.

In the future, smart e-government needs to tackle such challenges as facilitate smart services, protect citizens from cyber crime, strengthen democracy, develop a modern society with financial and social inclusion and reduce waste, fraud and abuse.

\section{CONCLUSION}

New research findings point to new trends and innovative methods, as well as the challenges and opportunities for e-government development. The public administration is facing more and more challenges, not only about effective e-government, but also about how to provide information and services to those, who do not have internet access or not own a bank account in an ever-growing world.

The objective of this research was to provide an overview of the current status of the Visegrad Group countries (the Czech Republic, Hungary, Poland and Slovakia) in e-government development from the point of view of E-government Development Index (EGDI) implemented into the world comparison by United Nations. EGDI measures the effectiveness of e-government in providing basic economic and social services in sectors such as education, health, work, employment, social welfare, finance and the environment.

It was found that the EDGI index values differ not only in terms of income and regional groups but also within the European Union. The monitored economies of the Visegrad Group are placed at the end of the EU ranking and disparities are not so big, but exist (between 18. place of Poland and 26. place of Czechia). Great progress has been made by Poland; on the other hand, the position of the Czech Republic has deteriorated from 2003 to 2018.

\section{ACKNOWLEDGMENT}

This research was supported by the grant project "SMART Technologies to Improve the Quality of Life in Cities and Regions" [grant number CZ.02.1.01/0.0/0.0/17_049/0008452]. 


\section{REFERENCES}

Alshomrani, S. (2012). Comparative Study on United Nations E-Government Indicators between Saudi Arabia and USA. Journal of Emerging Trends in Computing and Information Sciences, 3(3), pp. 411-420.

Alzahrani, A. I. (2011). Web-based e-government Services Acceptance for G2C: A Structural Equation Modelling Approach. PhD Thesis. Leicester, UK: De Montfort University.

Belanger, F. \& Carter, L. (2008) Trust and risk in e-government adoption. Journal of strategic information systems, 17(2), pp. 165-176. https://doi.org/10.1016/j.jsis.2007.12.002

Budiš, P. et al. (2008). e-Government bezpečně. Praha, Czech Republic: Grada Publishing.

Criado, J. I. (2012). Interoperability of e-government for Building Intergovernmental Integration in the European Union. Social Science Computer Review, 30(1), pp. 37-60. https://doi. org $/ 10.1177 / 0894439310392189$

Donna, E. \& Yen, D. C. (2006). E-government: evolving relationship of citizens and government, domestic, and international development. Government Information Quarterly, 23(2), pp. 207-235. https://doi.org/10.1016/j.giq.2005.11.004

EC (2016). Final Report - Study on "Analysis of the value of new generation of e-government services" (SMART 2014/066). Brussels, Belgium: European Commission.

Fernández-i-Marín, X. (2011). The Impact of e-Government Promotion in Europe: Internet Dependence and Critical Mass. Policy \&Internet, 3(4), Article 2. http://doi.org/10.2202/19442866.1093

Gupta, M. P. \& Jana, D. (2003). E-government evaluation: A framework and case study. Government Information Quarterly, 20(4), 365-387. http://dx.doi.org/10.1016/j.giq.2003.08.002

Halchin, L. E. (2004). Electronic government: Government capability and terrorist resource. Government Information Quarterly, 21(4), 406-419. http://dx.doi.org/10.1016/j.giq.2004.08.002

OECD (2009). General government expenditure. Government at a Glance 2009. Paris, France: OECD Publishing.

Šperka, R. (2014). The Process of E-government Implementation in Czech Republic: A 2014 Evaluation. In Proceedings of 12th International Scientific Conference Economic Policy In European Union Member Countries, Vendryně, September 12-14, 2014 (pp. 946-955). Karvina: Silesian University in Opava.

United Nations (2012). E-government Survey 2012. E-Government for the People. Geneva, Switzerland: UN.

United Nations (2018). E-Government Survey 2018. Gearing e-Government to support transformation towards sustainable and resilient societies. Geneva, Switzerland: UN.

WEF (2013). The Global Information Technology Report 2013: Growth and Jobs in a Hyper-connected World. Geneva, Switzerland: WEF.

Whitmore, A. (2012). A statistical analysis of the construction of the United Nation E-Government Development Index. Government Information Quarterly, 29(1), 68-75. http://dx.doi. org/10.1016/j.giq.2011.06.003 


\section{Appendix}

Table 2. EDGI of EU Member countries (plus Switzerland) in 2018 Source: United Nations, 2018

\begin{tabular}{|c|c|c|c|c|}
\hline & Level of income & EGDI & 2018 Rank & $\begin{array}{c}\text { Change in rank } \\
\text { (2016) }\end{array}$ \\
\hline Denmark & High income & 0.9150 & 1 & +8 \\
\hline United Kingdom & High income & 0.8999 & 4 & -3 \\
\hline Sweden & High income & 0.8882 & 5 & +1 \\
\hline Finland & High income & 0.8815 & 6 & -1 \\
\hline France & High income & 0.8790 & 9 & +1 \\
\hline Germany & High income & 0.8765 & 12 & +3 \\
\hline Netherlands & High income & 0.8757 & 13 & -6 \\
\hline Switzerland & High income & 0.8520 & 15 & +13 \\
\hline Estonia & High income & 0.8486 & 16 & -3 \\
\hline Spain & High income & 0.8415 & 17 & 0 \\
\hline Luxembourg & High income & 0.8334 & 18 & +7 \\
\hline Austria & High income & 0.8301 & 20 & -4 \\
\hline Ireland & High income & 0.8287 & 22 & +4 \\
\hline Italy & High income & 0.8209 & 24 & -2 \\
\hline Belgium & High income & 0.8080 & 27 & -8 \\
\hline Portugal & High income & 0.8031 & 29 & +9 \\
\hline Malta & High income & 0.8011 & 30 & 0 \\
\hline Poland & High income & 0.7926 & 33 & +3 \\
\hline Greece & High income & 0.7833 & 35 & +8 \\
\hline Slovenia & High income & 0.7714 & 37 & -16 \\
\hline Lithuania & High income & 0.7534 & 40 & -17 \\
\hline Hungary & High income & 0.7265 & 45 & +1 \\
\hline Bulgaria & Upper middle income & 0.7177 & 47 & +5 \\
\hline Slovakia & Upper middle income & 0.7155 & 49 & +18 \\
\hline Czech Republic & High income & 0.7084 & 54 & -4 \\
\hline Croatia & Upper middle income & 0.7018 & 55 & -18 \\
\hline Latvia & High income & 0.6996 & 57 & -12 \\
\hline Romania & Upper middle income & 0.6671 & 67 & +8 \\
\hline
\end{tabular}

